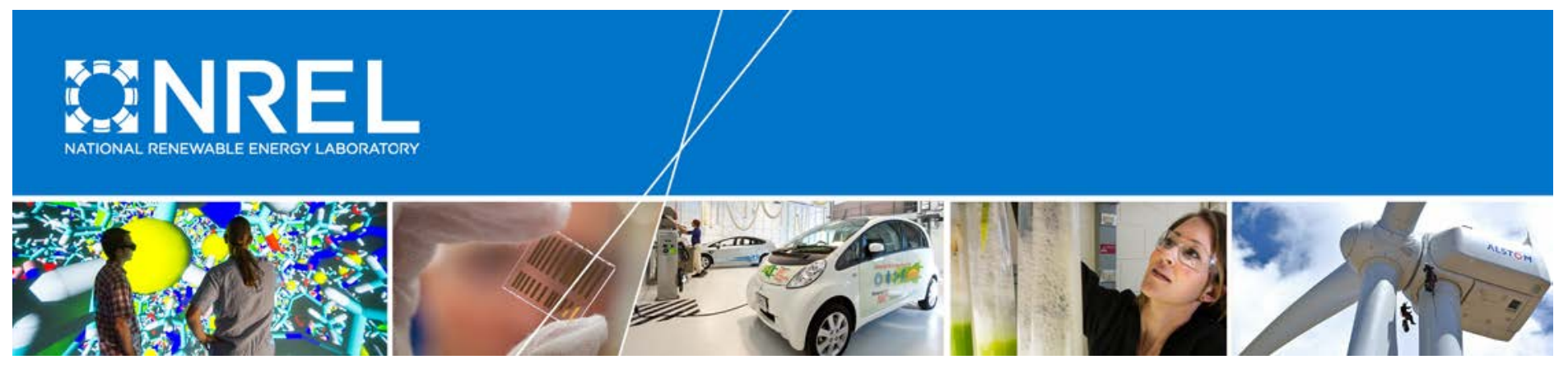

\title{
Terms, Trends, and Insights on PV Project Finance in the United States, 2018
}

David Feldman and Paul Schwabe National Renewable Energy Laboratory

NREL is a national laboratory of the U.S. Department of Energy Office of Energy Efficiency \& Renewable Energy Operated by the Alliance for Sustainable Energy, LLC

This report is available at no cost from the National Renewable Energy Laboratory (NREL) at www.nrel.gov/publications.

Technical Report

NREL/TP-6A20-72037

November 2018

Contract No. DE-AC36-08GO28308 


\section{Terms, Trends, and Insights on PV Project Finance in the United States, 2018}

\author{
David Feldman and Paul Schwabe \\ National Renewable Energy Laboratory
}

\section{Suggested Citation}

Feldman, David, and Paul Schwabe. 2018. Terms, Trends, and Insights on PV Project Finance in the United States, 2018. Golden, CO: National Renewable Energy Laboratory. NREL/TP-6A20-72037.

https://www.nrel.gov/docs/fy19osti/72037.pdf.
National Renewable Energy Laboratory 15013 Denver West Parkway

Golden, CO 80401

303-275-3000 • www.nrel.gov
NREL is a national laboratory of the U.S. Department of Energy Office of Energy Efficiency \& Renewable Energy Operated by the Alliance for Sustainable Energy, LLC

This report is available at no cost from the National Renewable Energy Laboratory (NREL) at www.nrel.gov/publications.

\section{Technical Report}

NREL/TP-6A20-72037

November 2018

Contract No. DE-AC36-08GO28308 


\section{NOTICE}

This work was authored by the National Renewable Energy Laboratory, operated by Alliance for Sustainable Energy, LLC, for the U.S. Department of Energy (DOE) under Contract No. DE-AC3608GO28308. Funding provided by the Solar Energy Technologies Office of the U.S. Department of Energy's Office of Energy Efficiency and Renewable Energy. The views expressed in the article do not necessarily represent the views of the DOE or the U.S. Government.

This report is available at no cost from the National

Renewable Energy Laboratory (NREL) at

www.nrel.gov/publications.

U.S. Department of Energy (DOE) reports produced

after 1991 and a growing number of pre-1991

documents are available

free via www.OSTI.gov.

Cover Photos by Dennis Schroeder: (left to right) NREL 26173, NREL 18302, NREL 19758, NREL 29642, NREL 19795.

NREL prints on paper that contains recycled content. 


\section{Acknowledgments}

This work was funded by the Solar Energy Technologies Office of the U.S. Department of Energy's Office of Energy Efficiency and Renewable Energy under contract number DE-AC3608GO28308. The authors would like to thank the following individuals and organizations for their insightful perspectives and review comments: David Burton of Mayer Brown; Alex Tiller and Laura York of Foss Renewable Energy Partners, LLC; Morgan Sell of Plan A Capital; Robert Margolis and Dan Bilello of NREL; Anna Ebers of DOE; and 5 additional interviewees who prefer to remain anonymous. The authors also thank Mike Meshek for his superb editorial support. 


\section{Executive Summary}

This report is a compilation of data points and market insights that reflect the state of the project finance market for solar photovoltaic (PV) assets in the United States as of the third quarter of 2018. We summarize some of the major developments affecting the cost of capital for PV projects in various market segments as well as the ease with which these funds are raised. We also summarize project-level solar PV financing cost data points that can be used as simplified benchmarks of the cost of capital and associated fees. All data compiled for the report are derived from a combination of a basic literature review, product research, and interviews with industry professionals.

Table ES-1 (next page) presents data for High-Cost, Low-Cost, and Mid-Cost financing scenarios for large distributed PV portfolios of third party owned projects, utility-scale PV projects owned by independent power producers, and smaller-dollar PV deals owned by third parties. The High-Cost and Low-Cost scenarios use the highest- and the lowest-cost values collected in our data set (respectively), while the Mid-Cost scenario represents the median value for these ranges. We also provide the number of data points we received for each value to give a sense of the robustness of each field. Both (1) our comparison of the values reported in Table ES-1 with those reported previously and (2) our discussions with interviewees suggest a modest reduction in the cost of equity for PV projects from 2017 to 2018, while debt interest rates stayed mostly unchanged. It is important that readers consider the data presented here as illustrative of trends and general market conditions rather than specific financing rates or investment requirements. This is particularly true given the limited sample size of interviewees and that a partnership flip structure with back leverage, while quite popular, represents one of many financing approaches currently used in the marketplace, and each has its own costs and terms.

Federal actions and market changes over the past year have impacted the cost of capital and how it is raised for third party owned and independent power producers PV projects. Despite these changes, the cost of capital for PV projects is comparable to that of recent years, with the midcase-adjusted weighted average cost of capital for data we collected ranging from $6.6 \%$ to $9.0 \%$, depending on market segment. Industry members we spoke to reported that tax equity providers were contributing a lower share of total project costs due the corporate tax rate reduction included in the Tax Cuts and Jobs Act of 2017 (Tax Act); however, despite supply constraints and the Base Erosion Anti-Abuse Tax (BEAT) ${ }^{1}$ provision in the tax act, tax equity providers required similar, or in some cases, lower rates of return. The diversity and number of sponsor equity providers continues to grow; they have been contributing a larger share of total project costs and in some cases have been willing to take construction risk or even invest in a project before a power contract has been secured. Debt providers are also contributing more to total project costs, and despite an increase in the underlying federal funds rate, they are offering similar pricing to last year. There has also been an expansion in the types of projects for which developers are seeking financing, with variations in the structure (e.g., virtual power purchase agreements and community solar) and lengths of contracts.

\footnotetext{
${ }^{1}$ The BEAT provision aims to prevent multinational companies from reducing their U.S. taxes by making tax deductible cross-border payments to foreign affiliates. One impact of this provision is that some multinational companies may only receive $80 \%$ of the value of the federal investment tax credit through 2025 , and potentially no value afterwards.
} 
Table ES-1. Ranges for Solar Finance Terms for Third Party Owned and Independent Power Producer Projects

\begin{tabular}{|c|c|c|c|c|c|c|c|c|c|c|c|c|}
\hline & \multicolumn{4}{|c|}{$\begin{array}{l}\text { Large Distributed PV Portfolios } \\
\text { (above } \$ 50 \text { million) }\end{array}$} & \multicolumn{4}{|c|}{$\begin{array}{l}\text { Utility-Scale PV Projects } \\
\text { (above } \$ 50 \text { million) }\end{array}$} & \multicolumn{4}{|c|}{$\begin{array}{l}\text { Smaller-Dollar PV Deals } \\
\text { (below \$25 million) }\end{array}$} \\
\hline & $\begin{array}{l}\text { Low- } \\
\text { Cost }\end{array}$ & $\begin{array}{l}\text { Mid- } \\
\text { Cost }\end{array}$ & $\begin{array}{l}\text { High- } \\
\text { Cost }\end{array}$ & $\begin{array}{c}\text { \# of } \\
\text { Data } \\
\text { Points }\end{array}$ & $\begin{array}{l}\text { Low- } \\
\text { Cost }\end{array}$ & $\begin{array}{l}\text { Mid- } \\
\text { Cost }\end{array}$ & $\begin{array}{l}\text { High- } \\
\text { Cost }\end{array}$ & $\begin{array}{c}\text { \# of } \\
\text { Data } \\
\text { Points }\end{array}$ & $\begin{array}{l}\text { Low- } \\
\text { Cost }\end{array}$ & $\begin{array}{l}\text { Mid- } \\
\text { Cost }\end{array}$ & $\begin{array}{l}\text { High- } \\
\text { Cost }\end{array}$ & $\begin{array}{c}\text { \# of } \\
\text { Data } \\
\text { Points }\end{array}$ \\
\hline \multicolumn{13}{|l|}{ Tax Equity } \\
\hline Percentage of project & $30.0 \%$ & $35.0 \%$ & $41.2 \%$ & 6 & $30.0 \%$ & $35.0 \%$ & $40.0 \%$ & 6 & $34.0 \%$ & $34.5 \%$ & $35.0 \%$ & 2 \\
\hline After-tax return at flip & $7.2 \%$ & $7.7 \%$ & $14.0 \%$ & 5 & $6.5 \%$ & $7.2 \%$ & $7.5 \%$ & 4 & $10.0 \%$ & $10.0 \%$ & $10.0 \%$ & 2 \\
\hline Total after-tax return & $7.2 \%$ & $8.8 \%$ & $18.2 \%$ & 4 & $7.2 \%$ & $8.3 \%$ & $9.0 \%$ & 3 & $13.0 \%$ & $13.0 \%$ & $13.0 \%$ & 2 \\
\hline \multicolumn{13}{|l|}{ Sponsor Equity } \\
\hline Percentage of project & $35.0 \%$ & $24.0 \%$ & $13.8 \%$ & $\mathrm{~N} / \mathrm{A}$ & $35.0 \%$ & $25.0 \%$ & $15.0 \%$ & $\mathrm{~N} / \mathrm{A}$ & $26.0 \%$ & $21.0 \%$ & $20.0 \%$ & N/A \\
\hline After-tax return & $7.0 \%$ & $9.0 \%$ & $20.0 \%$ & 6 & $5.9 \%$ & $7.3 \%$ & $8.5 \%$ & 5 & $10.0 \%$ & $10.0 \%$ & $10.0 \%$ & 3 \\
\hline \multicolumn{13}{|l|}{ Debt } \\
\hline Percentage of project & $35.0 \%$ & $41.0 \%$ & $45.0 \%$ & 7 & $35.0 \%$ & $40.0 \%$ & $45.0 \%$ & 5 & $40.0 \%$ & $44.5 \%$ & $45.0 \%$ & 2 \\
\hline Interest rate & $4.8 \%$ & $5.1 \%$ & $6.3 \%$ & 4 & $4.3 \%$ & $4.9 \%$ & $5.8 \%$ & 3 & $6.9 \%$ & $6.9 \%$ & $6.9 \%$ & 1 \\
\hline \multicolumn{13}{|l|}{ Other Financing Metrics } \\
\hline Debt service coverage ratio & 1.24 & 1.3 & 1.40 & 5 & 1.25 & 1.30 & 1.4 & 4 & 1.30 & 1.30 & 1.30 & 4 \\
\hline Term debt maturity (years) & 7 & 7 & 25 & 2 & 13 & 19 & 25 & 1 & 13 & 13 & 13 & 4 \\
\hline Upfront financing costs (\$ million) & $\$ 1.0$ & $\$ 1.2$ & $\$ 3.0$ & 5 & $\$ 1.0$ & $\$ 1.4$ & $\$ 3.0$ & 4 & $\$ 0.2$ & $\$ 0.4$ & $\$ 0.7$ & 1 \\
\hline Simple WACC ${ }^{a}$ & $5.5 \%$ & $6.7 \%$ & $11.1 \%$ & $\mathrm{~N} / \mathrm{A}$ & $3.2 \%$ & $6.1 \%$ & $6.8 \%$ & N/A & $9.1 \%$ & $8.9 \%$ & $8.8 \%$ & N/A \\
\hline Adjusted WACC & $5.6 \%$ & $7.5 \%$ & $10.4 \%$ & $\mathrm{~N} / \mathrm{A}$ & $5.1 \%$ & $6.6 \%$ & $7.5 \%$ & $\mathrm{~N} / \mathrm{A}$ & $9.2 \%$ & $9.0 \%$ & $9.0 \%$ & N/A \\
\hline
\end{tabular}


We also collected solar residential loan-rate and term data from 26 banking institutions and credit unions across the United States in the second quarter of 2018. A portion of solar loans provided in the marketplace receive interest rate buydowns which obscures the underlying financing rate. This data represents a sample of loans rates without interest rate buydowns. We present the high, median, and low annual percentage rate (APR) values for residential solar loans for customers with top-tier credit, in Table ES-2. We also provide the number of data points we received for each value to give a sense of the robustness of each field.

Table ES-2. Ranges of Non-Subsidized APR, Top-Tier Credit, for Residential Solar Loans

\begin{tabular}{|lc|c|c|c|c|} 
& \multicolumn{4}{c|}{$\begin{array}{c}\text { Personal or PV-Secured Solar Loan } \\
\text { Maximum Term (years) }\end{array}$} & $\begin{array}{c}\text { Real Estate-Secured Solar Loan } \\
\text { Maximum Term }\end{array}$ \\
\hline Median & $\mathbf{5 - 7}$ & $\mathbf{1 0}$ & $\mathbf{1 5}$ & $\mathbf{2 0}$ & $\mathbf{( 7 - 2 0}$ years) \\
\hline High & $6.8 \%$ & $6.2 \%$ & $6.1 \%$ & $7.1 \%$ & $4.5 \%$ \\
\hline Low & $9.0 \%$ & $9.0 \%$ & $9.0 \%$ & $7.2 \%$ & $5.7 \%$ \\
\hline Data points & $4.5 \%$ & $5.0 \%$ & $5.0 \%$ & $6.5 \%$ & $4.3 \%$ \\
\hline
\end{tabular}

The emergence of solar loans as a viable option for residential PV systems has caused a proliferation of product offerings by a variety of financial institutions. The APRs on these loans were primarily driven by the maximum loan term, the customer's credit score, whether the loan was secured against any real estate, the size of the loan, whether there were credit union membership discounts, and whether there were any interest-rate buy-downs by PV installers, state governments, or customers. The median APR for a high-credit residential PV loan data we collected ranged from $4.5 \%$ to $7.1 \%$, depending on the term length and security. For institutions that offered pricing data by credit score, the APR on loans for customers with the highest credit scores was approximately $2.5 \%$ lower than it was for those loans offered to those with the lowest acceptable credit scores (or profiles). Though this data set represents a large number of institutions, many customers do not pay these APRs due to the increasing popularity of interest rate buy-downs, which typically charge a fee of $2 \%-4 \%$ of the value of the loan for every $1 \%$ reduction in APR. The popularity of solar loans may be impacted after 2019 due to the differences between the Section 48 commercial and Section 25D residential tax credits, which allow third party owners to take higher credits in later years. 


\section{Table of Contents}

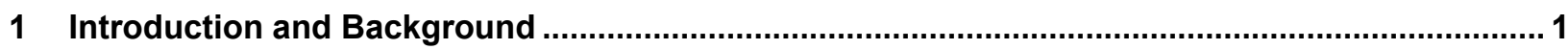

2 Methodology ............................................................................................................................. 2

2.1 Third Party Ownership and Independent Power Producer Financing ......................................... 2

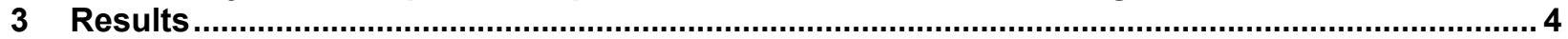

3.1 Third Party Ownership and Independent Power Producer Financing ................................... 4

3.2 Residential PV Loans ..................................................................................... 6

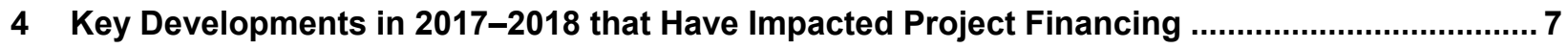

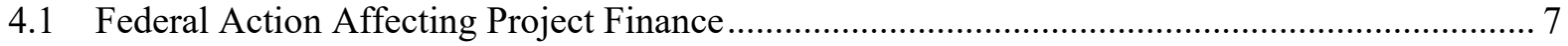

4.2 Insights on Changes in Project Finance .............................................................. 9

5 Conclusions ............................................................................................................................. 13

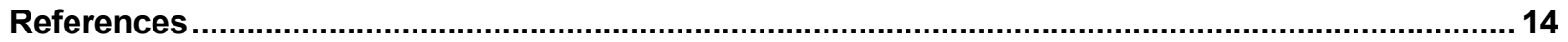




\section{List of Figures}

Figure 1. Example of a partnership flip structure

\section{List of Tables}

Table ES-1. Ranges for Solar Finance Terms for Third Party Owned and Independent Power

Producer Projects ...................................................................................................... vi

Table ES-2. Ranges of Non-Subsidized APR, Top-Tier Credit, for Residential Solar Loans.......................... vii

Table 1. Ranges for Solar Finance Terms for Third Party Owned and Independent Power

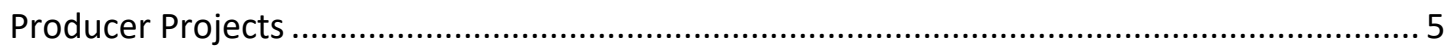

Table 2. Ranges of Non-Subsidized APR, Top-Tier Credit, for Residential Solar Loans.............................. 6 


\section{Introduction and Background}

This report is a compilation of data points and market insights that reflect the state of the project finance market for solar photovoltaic (PV) assets in the United States as of the third quarter of 2018. We summarize some of the major developments affecting the cost of capital for PV projects in various market segments as well as the ease at which these funds are raised. We also summarize project-level solar PV financing cost data points that can be used as simplified benchmarks of the costs of capital and associated fees. All data compiled for this report are derived from a combination of a basic literature review, product research, and interviews with industry professionals.

First, we look at three sources of capital used in traditional PV project financings of third party owned distributed projects and large-scale centralized projects owned by independent power producers - tax equity, sponsor equity, and debt. The costs associated with each source of capital are divided into three segments of the PV marketplace that traditionally have different costs and characteristics:

- Large distributed PV portfolios, which consist mostly of residential systems but might also include some commercial systems, with a total transaction value greater than $\$ 50$ million

- Utility-scale PV projects and portfolios that typically have a total transaction value greater than $\$ 50$ million

- Smaller-dollar PV deals consisting of individual commercial, community, or utility-scale PV projects, or portfolios of residential, commercial, or utility-scale projects ${ }^{2}$ that typically have a total transaction value of less than $\$ 25$ million.

We first compute a simple and adjusted weighted average cost of capital (WACC) across these segments for use in a variety of analyses, such as levelized cost of energy (LCOE) assessment or as financing inputs to models such as the National Renewable Energy Laboratory's (NREL's) System Advisor Model (SAM). Industry stakeholders can use these estimates to compare their actual costs to both the ranges and the median values of each capital source.

Second, we expand on previous editions of this report by providing a benchmark for the interest rates and terms of residential solar loan products with various tenors. This is accomplished by (1) collecting publicly available and published loan terms from 26 institutions, and (2) conducting a series of interviews with loan providers.

This work represents the third NREL effort to benchmark financing costs across the residential, commercial, and utility-scale PV markets, as part of a larger effort to benchmark the components of PV system costs. ${ }^{3}$ These efforts aim to facilitate transparency in the PV market and to measure progress toward meeting the 2030 cost targets of DOE's Solar Energy Technologies Office.

\footnotetext{
2 Transactions less than $\$ 25$ million generally involved individual projects or smaller portfolios of projects.

${ }^{3}$ For previous versions of this report, see Feldman, Lowder and Schwabe (2016) and Feldman and Schwabe (2017).
} 


\section{Methodology}

\subsection{Third Party Ownership and Independent Power Producer Financing}

To examine typical PV project financings of third-party-owned distributed projects and largescale centralized projects owned by independent power producers, we presented a partnership flip tax equity arrangement ${ }^{4}$ to interviewees and asked what changes, if any, occurred between 2017, when we last performed this analysis, and 2018 on financing terms for the debt, tax equity, and sponsor equity in the capital structure. We also requested general commentary on trends and developments in the capital markets that may not be captured in the financing metrics directly.

Figure 1 (next page) is a schematic of a simplified partnership flip structure that serves as the basis for this analysis. Several variations of this structure are currently employed by solar developers and financiers. ${ }^{5}$ While this structure is quite popular, it represents one of many financing approaches currently used in the marketplace, and each has its own costs and terms.

As shown in Figure 1, a lender (i.e., debt provider), a project sponsor, and a tax equity investor participate in this transaction; each investor provides a percentage of the total investment and expects a certain return. Interviewees provided either a single value or a range of values for each data field.

In the second quarter of 2018, we collected solar residential loan-rate and term data from 26 banking institutions and credit unions across the United States. The annual percentage rates (APRs) on these loans were primarily driven by the maximum loan term, the customer's credit score, whether the loan was secured against any real estate (e.g., home), the size of the loan, if there were credit union membership discounts, and whether there were any interest-rate buydowns by PV installers, state governments, or customers.

\footnotetext{
${ }^{4}$ A partnership flip involves equity investors, in this case the sponsor and tax-equity investors, which partner to invest in and own the project and share in its risks and rewards. Figure 1 is a schematic of a partnership flip that uses so-called "back leverage" (i.e., debt secured by the sponsor's interest in the partnership, rather than secured by the project). Back-levered debt is different from senior, project-level debt in that its claim on project cash flows are subordinate to those of the tax equity investor's.

${ }^{5}$ Partnership flip structures can vary based on whether the project allocations flip according to a predetermined date ("fixed-date" flip) or are they can be based on the tax equity's target yield ("yield-based" flip). Many experienced tax equity investors may also employ a combination of financing structures, such as an inverted lease built into a partnership flip. Newer tax-equity investors, however, are more likely to prefer a basic partnership flip as depicted in Figure 1, to keep transactions more straightforward.
} 


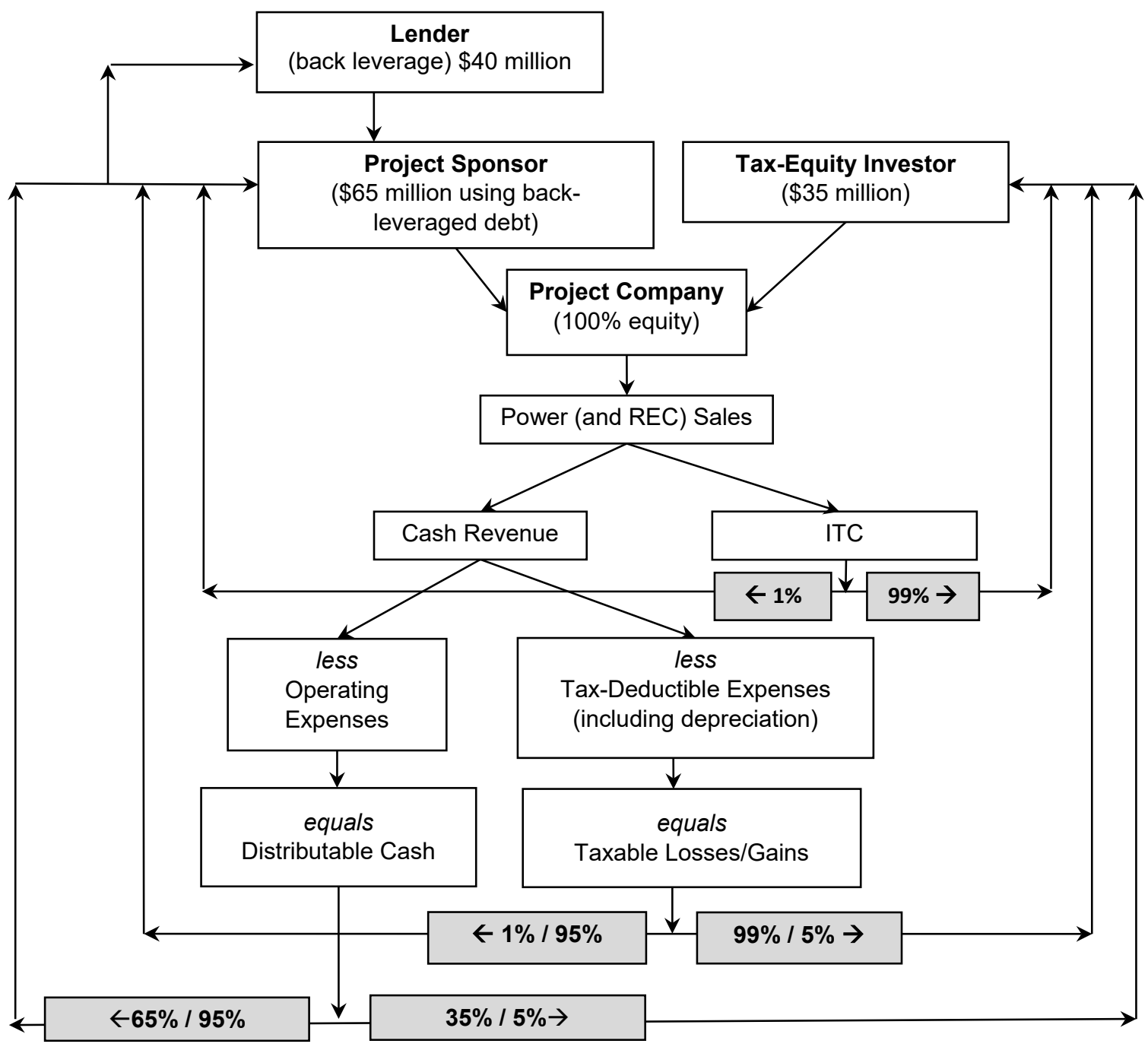

Figure 1. Example of a partnership flip structure

I = flip point in transaction where cash distribution and income allocation ratios are altered

ITC= investment tax credit, REC = renewable energy certificate 


\section{Results}

\subsection{Third Party Ownership and Independent Power Producer Financing}

Table 1 presents data for High-Cost, Low-Cost, and Mid-Cost financing scenarios for the three segments of the PV marketplace identified. The High-Cost and Low-Cost scenarios use the highest- and the lowest-cost values collected in our data set (respectively), ${ }^{6}$ while the Mid-Cost scenario represents the median value for these ranges. We also provide the number of data points we received for each value to give a sense of the robustness of each field; however, it should be noted that many of the values with fewer data points are fairly consistent with values reported in the previous year's benchmark.

\footnotetext{
${ }^{6}$ Because debt is a lower-cost source of capital than either source of equity, a lower percentage of debt in the capital structure makes for a higher-cost project. That said, investors use many different metrics to analyze projects. For example, on a pre-tax basis (i.e., project cash flows before tax payments are considered), tax equity receives a lower return than debt.
} 
Table 1. Ranges for Solar Finance Terms for Third Party Owned and Independent Power Producer Projects

\begin{tabular}{|c|c|c|c|c|c|c|c|c|c|c|c|c|}
\hline & \multicolumn{4}{|c|}{$\begin{array}{l}\text { Large Distributed PV Portfolios } \\
\text { (above } \$ 50 \text { million) }\end{array}$} & \multicolumn{4}{|c|}{$\begin{array}{l}\text { Utility-Scale PV Projects } \\
\text { (above } \$ 50 \text { million) }\end{array}$} & \multicolumn{4}{|c|}{$\begin{array}{l}\text { Smaller-Dollar PV Deals } \\
\text { (below } \$ 25 \text { million) }\end{array}$} \\
\hline & $\begin{array}{l}\text { Low- } \\
\text { Cost }\end{array}$ & $\begin{array}{l}\text { Mid- } \\
\text { Cost }\end{array}$ & $\begin{array}{l}\text { High- } \\
\text { Cost }\end{array}$ & $\begin{array}{l}\text { \# of Data } \\
\text { Points }\end{array}$ & $\begin{array}{l}\text { Low- } \\
\text { Cost }\end{array}$ & $\begin{array}{l}\text { Mid- } \\
\text { Cost }\end{array}$ & $\begin{array}{l}\text { High- } \\
\text { Cost }\end{array}$ & $\begin{array}{l}\text { \# of Data } \\
\text { Points }\end{array}$ & $\begin{array}{l}\text { Low- } \\
\text { Cost }\end{array}$ & $\begin{array}{l}\text { Mid- } \\
\text { Cost }\end{array}$ & $\begin{array}{l}\text { High- } \\
\text { Cost }\end{array}$ & $\begin{array}{l}\text { \# of Data } \\
\text { Points }\end{array}$ \\
\hline \multicolumn{13}{|l|}{ Tax Equity } \\
\hline$\%$ of project & $30.0 \%$ & $35.0 \%$ & $41.2 \%$ & 6 & $30.0 \%$ & $35.0 \%$ & $40.0 \%$ & 6 & $34.0 \%$ & $34.5 \%$ & $35.0 \%$ & 2 \\
\hline After-tax return at flip & $7.2 \%$ & $7.7 \%$ & $14.0 \%$ & 5 & $6.5 \%$ & $7.2 \%$ & $7.5 \%$ & 4 & $10.0 \%$ & $10.0 \%$ & $10.0 \%$ & 2 \\
\hline Total after-tax return & $7.2 \%$ & $8.8 \%$ & $18.2 \%$ & 4 & $7.2 \%$ & $8.3 \%$ & $9.0 \%$ & 3 & $13.0 \%$ & $13.0 \%$ & $13.0 \%$ & 2 \\
\hline \multicolumn{13}{|l|}{ Sponsor Equity } \\
\hline Percentage of project ${ }^{\mathrm{a}}$ & $35.0 \%$ & $24.0 \%$ & $13.8 \%$ & $\mathrm{~N} / \mathrm{A}$ & $35.0 \%$ & $25.0 \%$ & $15.0 \%$ & N/A & $26.0 \%$ & $21.0 \%$ & $20.0 \%$ & $\mathrm{~N} / \mathrm{A}$ \\
\hline After-tax return & $7.0 \%$ & $9.0 \%$ & $20.0 \%$ & 6 & $5.9 \%$ & $7.3 \%$ & $8.5 \%$ & 5 & $10.0 \%$ & $10.0 \%$ & $10.0 \%$ & 3 \\
\hline \multicolumn{13}{|l|}{ Debt } \\
\hline Percentage of project & $35.0 \%$ & $41.0 \%$ & $45.0 \%$ & 7 & $35.0 \%$ & $40.0 \%$ & $45.0 \%$ & 5 & $40.0 \%$ & $44.5 \%$ & $45.0 \%$ & 2 \\
\hline Interest rate & $4.8 \%$ & $5.1 \%$ & $6.3 \%$ & 4 & $4.3 \%$ & $4.9 \%$ & $5.8 \%$ & 3 & $6.9 \%$ & $6.9 \%$ & $6.9 \%$ & 1 \\
\hline \multicolumn{13}{|l|}{ Other Financing Metrics } \\
\hline Debt service coverage ratio & 1.24 & 1.3 & 1.40 & 5 & 1.25 & 1.30 & 1.4 & 4 & 1.30 & 1.30 & 1.30 & 4 \\
\hline Term debt maturity (years) ${ }^{\mathrm{b}}$ & 7 & 7 & 25 & 2 & 13 & 19 & 25 & 1 & 13 & 13 & 13 & 4 \\
\hline Upfront financing costs (\$ million) & $\$ 1.0$ & $\$ 1.2$ & $\$ 3.0$ & 5 & $\$ 1.0$ & $\$ 1.4$ & $\$ 3.0$ & 4 & $\$ 0.2$ & $\$ 0.4$ & $\$ 0.7$ & 1 \\
\hline \begin{tabular}{|l|l|} 
Simple WACC \\
\end{tabular} & $5.5 \%$ & $6.7 \%$ & $11.1 \%$ & $\mathrm{~N} / \mathrm{A}$ & $3.2 \%$ & $6.1 \%$ & $6.8 \%$ & $\mathrm{~N} / \mathrm{A}$ & $9.1 \%$ & $8.9 \%$ & $8.8 \%$ & $\mathrm{~N} / \mathrm{A}$ \\
\hline Adjusted WACC $^{c}$ & $5.6 \%$ & $7.5 \%$ & $10.4 \%$ & $\mathrm{~N} / \mathrm{A}$ & $5.1 \%$ & $6.6 \%$ & $7.5 \%$ & $\mathrm{~N} / \mathrm{A}$ & $9.2 \%$ & $9.0 \%$ & $9.0 \%$ & $\mathrm{~N} / \mathrm{A}$ \\
\hline
\end{tabular}

a The values of the percentage of sponsor equity in a project for each case displayed represent the remainder of project capital after debt and tax equity contributions, so that the three percentages total $100 \%$. Actual low and high values for sponsor equity collected in our analysis were large distributed PV portfolios (10\%-25\%); utility-scale PV projects (10\%-25\%); and small-scale PV projects (17.5\%).

b Term debt loans with maturity lengths of 4-7 years are typically "mini-perms," which are loans with a long-term amortization schedule but a shortdated maturity, such that a large "balloon" payment is due when the maturity is up. The balloon payment may be refinanced into another 4-7 year mini-perm.

"See previous edition of this report for the formula and detailed discussion of "adjusted WACC" (Feldman and Schwabe 2017). In addition to the values in the formula, the other assumptions used to calculate the adjusted WACC are (1) a tax equity flip-date of eight years, at which point tax equity ownership is assumed for the purposes of ease of this calculation purchased by sponsor equity, (2) a combined stated and federal tax rate of $25.7 \%$, and (3) a debt amortization of 18 years. 
Both (1) our comparison of the values reported in Table 1 with those reported previously and (2) our discussions with interviewees suggest a modest reduction in the cost of equity for PV projects from 2017 to 2018, while debt interest rates remained approximately the same. It is important that readers consider the data presented here as illustrative of trends and general market conditions rather than specific financing rates or investment requirements. This is particularly true given the limited sample size of interviewees and that a partnership flip structure with back leverage represents one of many financing approaches currently used in the marketplace.

\subsection{Residential PV Loans}

We present the high, median, and low APR values for residential solar loans for customers with top-tier credit, in Table 2 . We also provide the number of data points we received for each value to give a sense of the robustness of each field.

Table 2. Ranges of Non-Subsidized APR, Top-Tier Credit, for Residential Solar Loans

\begin{tabular}{lcccc|c} 
& \multicolumn{3}{c|}{$\begin{array}{c}\text { Personal or PV-Secured Solar Loan } \\
\text { Maximum }\end{array}$} & $\begin{array}{c}\text { Real Estate-Secured Solar Loan } \\
\text { Maximum Term } \\
\text { (y-20 years) }\end{array}$ \\
\hline Median & $\mathbf{5 - 7}$ & $\mathbf{1 0}$ & $\mathbf{1 5}$ & $\mathbf{2 0}$ & $4.5 \%$ \\
\hline High & $6.8 \%$ & $6.2 \%$ & $6.1 \%$ & $7.1 \%$ & $5.7 \%$ \\
\hline Low & $9.0 \%$ & $9.0 \%$ & $9.0 \%$ & $7.2 \%$ & $4.3 \%$ \\
\hline Data points & $4.5 \%$ & $5.0 \%$ & $5.0 \%$ & $6.5 \%$ & 4 \\
\hline
\end{tabular}

As shown in Table 2, loans secured by real-estate have lower rates. ${ }^{7,8}$ It should be noted that most loan providers do not offer products with all the max terms listed below; therefore, some of the variation in APR data is due to product variation among banking institutions. To isolate the impact of term length on interest rates, we looked at nine lending institutions that published multiple APRs for products of varying maximum terms. The APR for these institutions increased by approximately $0.9 \%$ for every five years of additional maximum loan term. We also looked at four institutions that offered multiple APRs for customers with varying credit scores. For these institutions, the APR on loans for customers with the highest credit scores was approximately $2.5 \%$ lower than those loans offered to those with the lowest acceptable credit scores (or profiles).

Though the data set used here represents a large number of institutions, many customers do not pay these APRs due to the increasing popularity of interest rate buy-downs. Loan providers often charge an upfront fee for lowering the interest rate that may be paid by the borrower or the solar provider. We have limited data on the cost of such buy-downs, but available data suggest that for every $1 \%$ reduction in APR a fee of $2 \%-4 \%$ of the value of the loan is incurred.

\footnotetext{
${ }^{7}$ Some within the solar industry have argued that the interest portion of solar loans secured by real estate—like with mortgage payments - and the principal portion of solar loans secured by real-estate - like with certain types of home repairs (U.S. Department of the Treasury 2015) - are tax deductible. There is no consensus, however, within the industry about whether one or both are tax deductible, and much of the debate is focused on how solar equipment is classified (e.g., real or personal property; home improvement or repair). Loan participants should consult with a tax advisor for their particular circumstances on whether the interest and principal portions of their loan are tax deductible (Feldman and Bolinger 2016).

${ }^{8}$ For a detailed discussion of the differences between secured- and non-secured PV loans, see Schwabe and Feldman (2018).
} 


\section{Key Developments in 2017-2018 that have Impacted Project Financing}

In this section, we review federal actions that occurred over the past year that affect the PV project finance market, and we then summarize how these and other market changes have impacted the cost of capital and how it is raised for PV projects.

\subsection{Federal Action Affecting Project Finance}

\subsubsection{Tax Changes}

Several provisions of the Tax Act, which signed into law on December 22, 2017, impact PV economics for some or all investors in the project finance space.

The first change affecting investors is the reduction in the federal corporate tax rate from $35 \%$ to $21 \%$. This change lowers the demand for tax credits by reducing the amount of taxes paid by corporations. ${ }^{9}$ The lowering of the corporate tax rate also reduces the benefits of depreciation expense. Depreciation expense is a deduction that lowers a company's taxable income. Because income will be taxed at a lower rate, the "sheltering" effect of depreciation is worth less.

The second change to project economics is the ability for project owners to immediately expense $100 \%$ of new and old equipment from 2018 to 2022. Starting in 2023, the percentage of capital equipment that can be expensed drops $20 \%$ per year (i.e., $80 \%$ in 2023 and $60 \%$ in 2024 and so forth) until the prevision reaches $0 \%$ in 2027 . Solar energy projects are normally depreciated over a five-year schedule, although over the past decade have received "bonus" depreciation, which allowed system owners to depreciate some or all of their project investments in the first year. That said, many renewable energy investors did not previously use bonus depreciation because they preferred to spread their tax appetite over more projects or use it against tax credits that have more favorable financial statement treatments. Investors may also elect not to use $100 \%$ expensing for the same reasons.

Another provision that has the possibility of affecting certain PV tax equity investors is the Base Erosion Anti-Abuse Tax (BEAT) provision of the Tax Act. The BEAT provision aims to prevent multinational companies from reducing their U.S. taxes by making tax-deductible cross-border payments to foreign affiliates. Under BEAT, two tax payments are calculated, and a company must pay the higher of:

- Calculation 1: $10 \%{ }^{10}$ of taxable income (not including any cross-border deductions for payments to related parties)

- Calculation 2: Corporation's regular tax liability reduced by most tax credits.

\footnotetext{
${ }^{9}$ Though the effective tax rate change may not be as substantial as the absolute values listed above, most estimates (e.g., Congressional Budget Office estimates) project a decrease in tax receipts from corporations. The Penn Wharton Budget Model calculates that across all industries the tax bill will decrease the corporate tax rate from $21 \%$ to $9 \%$ in 2018 , from $24 \%$ to $17 \%$ in 2023 , and from $23 \%$ to $19 \%$ in 2027 ; however, the estimates vary widely by industry (Penn Wharton Budget Model, 2017).

${ }^{10}$ The percentage is $11 \%$ for banks and securities dealers. Tax rate starts at $5 \%$ in $2018(6 \%$ for banks and securities dealers) and increases to $12.5 \%$ (13.5\% for banks and securities) after 2025 .
} 
The Tax Law allows companies to exclude all research and development tax credits and $80 \%$ of energy and low-income tax credits until 2026 in Calculation 1, meaning companies may only receive $80 \%$ of value of federal investment tax credit (ITC). Because of all the variables in the calculation, many companies may have to wait until the end of year to know for certain how much of the tax credits they can use. The 2025 end-date will affect wind projects more than solar projects because wind production tax credits (PTC) are taken over ten years; some wind projects in lower-resource areas could consider taking the ITC in lieu of the PTC (Martin 2017; Cooper et al. 2017).

Starting in 2018, a company's net interest expense will be limited to $30 \%$ of its adjusted taxable income (not including interest expense, interest income, and net operating losses). This change will not affect many businesses immediately because adjusted taxable income will not include interest deduction, depreciation, amortization, or depletion until 2022. Interest deductions can be carried forward and the limit does not apply to (1) companies with average gross receipts of $\$ 25$ million or less or (2) regulated public utilities. Because of these limitations, Congress has estimated the provision will not affect 95\% of business through 2021 (Martin 2017).

However, the new interest limitation causes a problem for tax equity partnerships incurring debt (i.e., front leverage) because more than $35 \%$ of the partnerships' tax losses are allocated to the tax equity investor who does not actively participate in management. This means the tax equity partnership is deemed a "syndicate" and ineligible for the \$25 million gross receipts exception. The result is the tax equity partnership would be unable to deduct interest in excess of the $30 \%$ limit (Burton, Davis, and Levin-Nussbaum 2018). This outcome appears to have been an unintended consequence of the Tax Act, and it represents another reason to use back-leverage and shift the onus of the interest deduction to the sponsor.

Other notable changes to the tax code include:

- Changes to prepaid power contracts, which now must immediately be reported as income; previously, income could be reported when the electricity was delivered, delaying tax payments.

- Transfer of partnership interests will not cause a termination of the partnership for tax purposes; some partners had previously gone to great lengths to avoid such a termination); corporations must now report government grants as income.

- Mandatory repatriation, which subjects all untaxed earnings (post-1986) in offshore holding companies by U.S. companies to a $15.5 \%$ tax, if they are cash, and $8 \%$ otherwise; this repatriation could increase the demand for tax credits or income offsets.

\subsubsection{Section 201 Tariff}

On February 7, 2018, President Trump issued a proclamation imposing safeguard tariffs on imported crystalline silicon PV cells and modules. The four-year tariff begins at $30 \%$ of the cost of the modules or cells in 2018 and drops 5\% points each year thereafter. Some product and country exclusions have been granted; the largest exclusion is for 2.5 gigawatts of imported PV cells to support domestic module assembly manufacturers. While PV module prices in the U.S. have risen, and PV module prices in other parts of the world have fallen, since the possibility of such a tariff was first raised (GTM Research 2018), future analysis will be needed to determine the long-term impact of the tariff on prices. For a detailed discussion on U.S. module costs, see 
Fu et al. (2018). Some developers have announced project cancellations (e.g., Cypress Creek and Southern Current) (Groom 2018), while others within the industry have predicted projects will be delayed until 2019, or later, when the tariff rate lowers. The year 2019 could be particularly busy, as it is scheduled to be the last year PV projects can commence construction to receive the full $30 \%$ federal tax credit; and, there will be a lower tariff on imported modules and cells in 2019.

\subsubsection{Four-Year Commence Construction Language Clarified by IRS}

The Consolidated Appropriations Act, 2016 (H.R. 2029) extended the ITC for PV systems so that projects under construction before 2020 receive the full $30 \%$ credit. The credit then falls to $26 \%$ for projects starting construction in 2020 and $22 \%$ for projects starting construction in 2021. For any solar project that starts construction after 2021, or which fails to be placed in service by January 1, 2024, the ITC reverts to $10 \%$. In June 2018, the IRS published clarifying guidance on what project owners and developers must do to be considered "under construction" and thus qualify for the ITC. While several key provisions apply, a project can generally be considered "under construction" in one of two ways, according to Martin (2018a):

- Starting "physical work of significant nature" and continuously constructing it, or completing it within a four-year window

- Incurring $5 \%$ of the cost of the final cost of a project associated with equipment that is integral to electricity generation.

\subsubsection{Federal Reserve Increases its Target Interest Rate}

The federal funds rate represents the interest rate banks charge other banks for overnight loans, and it is effectively set by the Federal Reserve. Banks typically base the rates they charge customers on the federal funds rate. In 2017, the Federal Reserve increased its target federal funds rate three times, increasing it that year from $0.75 \%$ to $1.50 \%$. In 2018 , the Federal Reserve has increased its target an additional two times - to $2.0 \%$ - and indicated it would likely increase the target two more times this year (Ydstie 2018; Federal Reserve 2018).

\subsection{Insights on Changes in Project Finance}

In addition to benchmarking financial terms, we interviewed industry professionals and reviewed literature regarding 2018 project finance trends for PV assets. The following topics represent major themes mentioned by multiple sources, including industry interviews.

\subsubsection{Impact of the Recent Federal Changes}

Tax equity providers are contributing a lower share of total project costs because of the corporate tax rate reduction included in the Tax Act. A lower tax rate reduces the value of the depreciation, which tax equity investors use to offset other income, and it increases the value of later-year profit (typically when a sponsor may own the asset) as less taxes will be paid on earnings. The lower corporate tax rate also makes the residual interest held by the tax equity investor after the partnership allocation flip more valuable. This has the unintended consequence of making it more expensive for sponsors to buy out tax equity investors when exercising a "then" fair market value purchase option. 
The reduction in tax equity contribution is mostly offset by an increase in sponsor equity contribution. This aligns with the sentiment interviewees stated that cash represents a larger portion of a project's return than tax benefits. Deficit restoration obligations provided by some tax equity investors are also increasing to enable their capital accounts to absorb more accelerated depreciation. Additionally, some tax equity investors have started agreeing to lower caps on indemnity cash sweeps, so enough cash is available to distribute to the sponsors to service back-levered loans (Berger and Rosenberg 2018). ${ }^{11}$ Interviewees also stated that most investors are not electing to immediately expense (i.e., depreciate) the full cost of a system, preferring to deduct the cost of the system over time. That said, some investors elected to use bonus depreciation in 2017 to take advantage of the higher tax rate before it lowered in 2018 .

More debt is also being raised for projects to offset the lower tax equity contributions. This increase is partially caused by a possible slight reduction in required debt service coverage ratios from debt providers. Additionally, despite the increase in the underlying federal funds rate, most investors are reporting no change in the cost of debt. This may be caused by the large number of banks participating in the sector and the competition on rates lenders may charge.

Despite supply constraints of tax equity and the BEAT provision in the Tax Act, this year's required rate of return for tax equity investors is similar to the rates from last year, and in some cases, it is lower. The BEAT provision has the potential to reduce the benefit of renewable energy tax credits by $20 \%$, both for new and existing projects. Despite this change, it has thus far not affected the value that tax equity investors are willing to attribute to the tax credits when evaluating a project; investors have either stayed-in the space with value attributed to the tax credits at competitive rates, moved to a business model of originating tax equity to syndicate it, or left the space. However, many interviewees also said that the full impact of the BEAT provision still represents an open question, as companies assess all the large tax changes and BEAT's impact on tax credits will be five times greater starting in 2026 (Burton and Davis 2018).

\subsubsection{Other Changes to PV Project Finance}

Though this report benchmarks the rate of return (i.e., yield) required by investors, many tax equity investors are moving away from evaluating projects by yield and instead looking at their return on investment. The difference between the two is that no time element is used in the calculation of return on investment; given the shorter timeframe in which tax equity is involved in a project (with many targeting to exit after six years), it may provide a better metric and values as it removes the large fluctuation in yield that can occur from small changes in timing of receiving the large upfront benefits from the ITC and accelerated depreciation. Reported market return on investment from interviewees ranged from $7 \%$ to $18 \%$ with a median of $11 \%$.

\footnotetext{
${ }^{11}$ Indemnity cash sweeps occur when tax equity investors are required to pay more taxes than expected because the tax credit is worth less than originally calculated and agreed to by the sponsor equity. In those instances, sponsors often agree to indemnify the tax equity investor from a loss in value through a "cash sweep" of project cash flows. These cash sweeps can be problematic when the cash would have been distributed to sponsor equity investors to service their back-levered debt. Some transactions limit the percentage of cash that can be swept in a cash sweep so that there is always enough cash to service the debt. By tax equity investors agreeing to a lower percentage limit for their maximum cash sweep, they put sponsor equity in a better position to raise back-levered debt.
} 
Interviewees also reported that the partnership flip structure is still very popular in the marketplace, but some tax equity investors in ITC deals are moving toward flipping economic sharing ratios at a certain date (i.e., "date-certain flips") or are adding debt at the project level (rather than back-levering at the corporate level).

\subsubsection{Changes to the Pool of Investors and Projects}

The diversity and number of financiers in the marketplace continues to grow, with new investors entering the market from sectors as diverse as the food and beverage space, infrastructure funds (both foreign and domestic), Canadian independent power producers, developers, commercial banks, small tax equity investor syndicates, and regional banks. Some companies invest equity to satisfy environmental or energy goals. Martin (2018b) estimates there are currently 15-17 active solar tax equity investors (and 35 investors between wind and solar). The increase in the number of investors has lowered project yields and has caused some investors to offer more favorable terms, such as taking construction risk or even investing in a project before a power contract is secured.

The tax equity market continues to be bifurcated into (1) large institutions that only invest in large projects with very high credit offtakers and (2) more opportunistic investors who are more willing to look at smaller deals with a broader profile of energy offtakers. Tax equity investors typically require higher returns on these smaller projects (as shown in Table 1); however, interviewees also noted that these types of projects often spend less on transaction costs (in sum, not per watt) by using less-expensive transactional advisors (i.e., law and accountancy) or performing less due diligence.

Despite the increase in the number of investors, seasonal changes affect the supply and demand balance throughout the year. Fewer investors are typically in the marketplace in the middle of the year because many companies do not have a reliable projection of their tax capacity for the year until the third or fourth quarter of the year, at which point many projects may be gone. The Tax Act has contributed to this issue as companies are paying less taxes and performing more calculations to estimate the optimal amount of tax credits needed.

In addition to the increasing share of corporate - or virtual power purchase-agreements, which use fixed-for-floating swaps, ${ }^{12}$ hedge providers are also now offering proxy revenue swaps in the solar space. These contracts, which are not tied to energy output, pay developers a fixed payment in exchange for a variable amount determined by the amount of sunlight a project receives (Brozynaki 2018). Power purchase agreements are also being signed for shorter durations-for example, for many projects in North Carolina - meaning financiers must get more comfortable with the value of a project after the contracted output period. Finally, community solar projects are entering the marketplace, though many investors have reported difficulty finding a way to get comfortable with the risks. Some investors restrict the percentage of residential customers in a community solar investment, with many reporting a maximum of $20 \%$. Additionally, investors often require that the residential portion of a community solar project be oversubscribed. That said, one interviewee stated that projects with utility power purchase agreements now represent the minority of projects in the marketplace; in fact, corporate power purchase agreements are not

\footnotetext{
${ }^{12}$ See Schwabe et al. (2017) for a detailed discussion of these contracts.
} 
necessarily seen as a higher risk, as many corporations have existing relationships with banks involved in project finance.

\subsubsection{The Emergence of Solar Loans and Potential Impact of IRS "Commence Construction" Clarification}

From 2012 to 2014, third party ownership of residential PV systems, including leases and powerpurchase agreements represented $62 \%$ to $72 \%$ of the U.S. market. Beginning in 2015, market share for third party ownership decreased while PV loans and cash purchases grew. By 2017 , third party ownership fell to $41 \%$ of annual installations while loans made up $33 \%$ of the market (the remainder were direct purchases). The increase in PV loans and cash purchases was due to several factors, including declining PV system costs, more widespread loan availability, and changing business models of national installers among other reasons (Mond 2018). Through 2019, homeowners who purchase PV systems are scheduled to receive a 30\% ITC, under Section $25 \mathrm{D}$ of the tax code. As with the business ITC, under Section 48 of the tax code, the 25D tax credit is scheduled to reduce to $26 \%$ in 2020 and $22 \%$ in 2021 . However, unlike with Section 48, credit homeowners must place their PV system in service in the qualifying year of the tax credit, as opposed to commencing construction. The recent guidance published by the IRS, which effectively give many project owners four years to qualify for the Section 48 credit, puts host-owned residential PV projects at a greater disadvantage. This imbalance will likely be exacerbated in 2022 and 2023, when third party ownership providers may still be able to receive a $30 \%$ ITC, but homeowners would receive no ITC if they were to purchase a system. 


\section{Conclusions}

Federal actions and other market changes over the past year have impacted the cost of capital and how it is raised for PV projects. Despite these changes, the cost of capital for PV projects is comparable to that of recent years, with the mid-case-adjusted WACC for data we collected ranging from $6.6 \%$ to $9.0 \%$, depending on market segment. Industry members we interviewed reported that tax equity providers were contributing a lower share of total project costs due the corporate tax rate reduction included in the Tax Act; however, despite supply constraints and the BEAT provision in the Tax Act, tax equity providers required comparable, or in some cases, lower rates of return. The diversity and number of sponsor equity providers continues to grow; they have been contributing a larger share of total project costs and in some cases have been willing to take construction risk or even investing in a project before a power contract is secured. Debt providers are also contributing more to total project costs and despite an increase in the underlying federal funds rate are offering similar pricing to last year. There has also been an expansion in the types of projects for which developers are seeking financing, with variations in the structure (e.g., virtual power purchase agreements and community solar) and lengths of contracts.

The emergence of solar loans as a viable option for residential PV systems has caused a proliferation of product offerings by a variety of financial institutions. The APRs on these loans were primarily driven by the maximum loan term, the customer's credit score, whether the loan was secured against any real estate, the size of the loan, whether there were credit union membership discounts, and whether there was any interest-rate buy-downs by PV installers, state governments, or customers. The median APR for a high-credit residential PV loan data we collected ranged from $4.5 \%$ to $7.1 \%$, depending on the term length and security. For institutions that offered pricing data by credit score, the APR on loans for customers with the highest credit scores was approximately $2.5 \%$ lower than it was for loans offered to those with the lowest acceptable credit scores (or profiles). Though this data set represents a large number of institutions, many customers do not pay these APRs because of the increasing popularity of interest rate buy-downs which typically charge a fee of $2 \%-4 \%$ of the value of the loan for every $1 \%$ reduction in APR. The popularity of solar loans may be impacted after 2019 due to the differences between the Section 48 commercial and Section 25D residential tax credits, that allow third party owners to take higher credits in later years. 


\section{References}

Berger, Jim, and Amanda Rosenberg. 2018. "Tax Equity Primer for Back-Levered Lenders.” Project Finance NewsWire. February 2018.

Brozynaki, Christine. 2018. "Proxy Revenue Swaps for Solar.” Norton Rose Fulbright. June 6, 2018. http://www.nortonrosefulbright.com/knowledge/publications/167467/proxy-revenue-swaps-for-solar

Burton, David, and Jeffrey Davis. 2018. "What is the Impact of Tax Reform on US Wind Tax Equity Deals?" Tax Equity Times. January 18, 2018. https://www.taxequitytimes.com/2018/01/impact-taxreform-us-wind-tax-equity-deals/.

Burton, David, Jeffrey Davis, and Anne S. Levin-Nussbaum. 2018. "2018 and Onward: The Impact of Tax Reform on the Renewable Energy Market.” Pratt's Energy Law Report. March 2018.

Cooper, Heather, Martha Groves Pugh, Kevin Spencer, Philip Tingle. 2017. "Renewable Energy Tax Bill Update: No Change to PTC and ITC and Some BEAT Changes." McDermott, Will \& Emery. December 21, 2017. https://www.mwe.com/en/thought-leadership/publications/2017/12/renewable-energy-tax-billupdate-no-change-ptc-itc.

Federal Reserve (Board of Governors of the Federal Reserve System). 2018. "Policy Tools." Accessed August 28, 2018: https://www.federalreserve.gov/monetarypolicy/openmarket.htm.

Feldman, David, and Mark Bolinger. 2016. On the Path to SunShot: Emerging Opportunities and Challenges in Financing Solar. Golden, CO: National Renewable Energy Laboratory. NREL/TP-6A2065638. http://www.nrel.gov/docs/fy16osti/65638.pdf.

Feldman, David, Travis Lowder, and Paul Schwabe. 2016. "Terms, Trends, and Insights PV Project Finance in the United States, 2016." Golden, CO: National Renewable Energy Laboratory. NREL/BR6A20-66991. https://www.nrel.gov/docs/fy16osti/66991.pdf.

Feldman, David, and Paul Schwabe. 2017. Terms, Trends, and Insights PV Project Finance in the United States, 2017. Golden, CO: National Renewable Energy Laboratory. NREL/TP-6A20-70157. https://www.nrel.gov/docs/fy18osti/70157.pdf.

Fu, Ran, David Feldman, and Robert Margolis. 2018. U.S. Solar Photovoltaic System Cost Benchmark: Q1 2018. Golden, CO: National Renewable Energy Laboratory. NREL/TP-6A20-72399.

Groom, Nichola. 2018. "Billions in U.S. Solar Projects Shelved after Trump Panel Tariff." Reuters. June 7, 2018.

GTM Research and SEIA (Solar Energy Industries Association). 2018. U.S. Solar Market Insight Report, Q2 2018. Washington, D.C.: Solar Energy Industries Association.

Martin, Keith, 2017. "How the US Tax Changes Affect Transactions." Project Finance NewsWire. December 2017.

Martin, Keith. 2018a. “IRS Issues Solar Construction-Start Guidance: Notice 2018-59.” Norton Rose Fulbright. June 22, 2018.

Martin, Keith. 2018b. "Cost of Capital: 2018 Outlook.” Project Finance NewsWire. February 2018.

Mond, Allison. 2018. U.S. Residential Solar Finance Update, H1 2018. Boston: GTM Research. 
Penn Wharton Budget Model. 2017. "Budget Model: The Tax Cuts and Jobs Act, as Reported by Conference Committee (12/15/17): Tax Effects by Industry.” December 18, 2017.

http://budgetmodel.wharton.upenn.edu/issues/2017/12/15/effective-tax-rates-by-industry.

Schwabe, Paul, David Feldman, Jason Fields and Edward Settle. 2017. Wind Energy Finance in the United States: Current Practice and Opportunities. Golden, CO: National Renewable Energy Laboratory. NREL/TP-6A20-68227. https://www.nrel.gov/docs/fy17osti/68227.pdf.

U.S. Department of the Treasury. 2015. "Your Federal Income Tax for Individuals: Tax Guide 2014 for Individuals.” Internal Revenue Service Publication 17 Catalog Number 10311G. February 6, 2015.

Ydstie, John. 2018. “Fed Raises Interest Rates, Signals 2 More Hikes This Year.” NPR. June 13, 2018. https://www.npr.org/2018/06/13/619212907/interest-rates-expected-to-go-up-with-more-hikes-to-come. 